\title{
Article \\ A Two-Stage SEM-Artificial Neural Network Analysis of Mobile Commerce and Its Drivers
}

\author{
Anca Antoaneta Vărzaru ${ }^{1, *(\mathbb{D})}$ and Claudiu George Bocean ${ }^{2}$ (D) \\ 1 Department of Economics, Accounting and International Business, University of Craiova, \\ 200585 Craiova, Romania \\ 2 Department of Management, Marketing and Business Administration, University of Craiova, \\ 200585 Craiova, Romania; bocean.claudiu@ucv.ro \\ * Correspondence: anca.varzaru@edu.ucv.ro; Tel.: +407-7392-1189
}

check for

updates

Citation: Vărzaru, A.A.; Bocean, C.G. A Two-Stage SEM-Artificial Neural Network Analysis of Mobile Commerce and Its Drivers. J. Theor. Appl. Electron. Commer. Res. 2021, 16, 2304-2318. https://doi.org/10.3390/ jtaer16060127

Academic Editors: Francesco Bellini, Alina Mihaela Dima, Alessio

Maria Braccini and Rocco Agrifoglio

Received: 26 July 2021

Accepted: 7 September 2021

Published: 9 September 2021

Publisher's Note: MDPI stays neutral with regard to jurisdictional claims in published maps and institutional affiliations.

Copyright: (c) 2021 by the authors. Licensee MDPI, Basel, Switzerland. This article is an open access article distributed under the terms and conditions of the Creative Commons Attribution (CC BY) license (https:/ / creativecommons.org/licenses/by/ $4.0 /)$.

\begin{abstract}
The COVID-19 health and economic crisis has affected all areas of social life globally, including the economy. The world economy has declined due to purchasing power for individuals who have been forced to stay at home and cannot perform work. These restrictions to prevent the spread of SARS-Cov-2 have led to an increase in electronic commerce and mobile commerce as tools for procuring goods and services. In this paper, we conducted a longitudinal analysis of mobile commerce as an essential electronic commerce component, establishing the main drivers of mobile commerce and the intensity of their influences. The research focuses on mobile commerce in the United States (U.S.). It covers the period 2010-2020, the last year of this period capturing the context of the COVID-19 pandemic and its impact on electronic commerce (e-commerce) and mobile commerce (m-commerce). In the macroeconomic analysis of competitiveness, we established the main drivers of $\mathrm{m}$-commerce, using artificial neural networks and the mediation effects found between the variables that describe m-commerce, e-commerce, and total sales, using structural equation modeling. The research results indicate an increase in the share of e-commerce in total sales and a predominance of the $\mathrm{m}$-commerce share in e-commerce on the background of traffic restrictions and social distance rules imposed due to the COVID-19 pandemic. Stakeholders in the m-commerce area should consider the following enhancing drivers: increasing internet speed, expanding 5G and Wi-Fi networks, and increasing accessibility and trust in mobile devices and applications.
\end{abstract}

Keywords: m-commerce; e-commerce; total sales; GDP; mobile device; internet users; U.S.

\section{Introduction}

Today, trade is going through an unprecedented stage of dynamism and innovation. Technological leaps increase productivity and facilitate the sales process. In addition, consumer behavior and expectations evolve, which generates new business models that will profoundly influence commerce in general, especially e-commerce. According to some estimates, e-commerce will reach USD 4.9 trillion in 2021, increasing by $14 \%$ compared to 2020 [1]. Furthermore, due to the expansion of mobile devices (smartphones and tablet PCs) and their ubiquity in the lives of individuals, mobile commerce (m-commerce) has distinguished itself as an additional sales channel.

The social distancing rules established due to the COVID-19 pandemic have substantially changed sales business models, forcing several consumers, who would not usually use mcommerce, to turn to this channel [1,2]. According to [2], the effect of the COVID-19 pandemic will lead to an increase in long-term mobile commerce, but some of the new consumers integrated into $\mathrm{m}$-commerce will return to e-commerce or traditional trade (offline). There are estimates that by 2023, there will be approximately 1.3 billion mobile payment users globally [3]. However, a lot of studies can be found in the literature [4-10], where several uncertainties can be noted regarding the motivation of consumers to continue using mobile commerce, the advantages perceived by consumers in the use of mobile commerce, and the 
comparison of these advantages with the benefits offered by other channels. According to [11], m-commerce can only sustain upward trends because it combines all its services. M-commerce uses the most modern tools to achieve sales and will become a dominant force in global trade due to the multiple services offered, design, and content features [12]. Dumanska et al. [13] note a relatively rapid transition of consumers to e-commerce and chiefly $\mathrm{m}$-commerce due to technical development, globalization, liberalization of international trade, and fluctuations in consumption habits, phenomena that have profoundly influenced the development of global commerce from old-style methods to online.

Given the health rules and traffic restrictions generated by the COVID-19 pandemic, it can be observed that changes in consumer behavior influence the growth of e-commerce sales, especially $\mathrm{m}$-commerce. Social distancing is necessary to create a physical space between individuals to avoid transmitting diseases and combat the danger of contagion [14]. According to World Health Organization (WHO) recommendations, the most effective way to implement social distancing is to carry out all activities at home (work at home and online communication, online education, online medicine, online commerce). During strict lockdown periods, almost all need for goods was assumed as a place of delivery-the residence-and a tool of ordering and even paying via the internet. E-commerce and $\mathrm{m}$-commerce have benefited from the restrictions because they offer the facility to purchase goods and services regardless of location. This phenomenon shows that the COVID-19 pandemic causes negative effects and losses; still, positive stakes, opportunities, and challenges can facilitate the intensification of innovation implementation in the industrial revolution 4.0 [15].

Given the dynamic and rapid changes in the m-commerce and e-commerce segment, it is necessary to research their developments, macroeconomic analysis of the drivers of $\mathrm{m}$ commerce, and the potential mediation effects established between the variables describing $\mathrm{m}$-commerce, e-commerce, and total sales. These analyses help set trends in m-commerce and e-commerce. The research question was posed in this context: how has m-commerce evolved in the last eleven years, and what are the main drivers that influence this evolution? Starting from the research question, the purpose of this paper is a longitudinal analysis of U.S. m-commerce at the macroeconomic level by using different types of analysis and statistical models: correlation analysis, comparative analysis, analysis of artificial neural networks, and modeling of structural equations. Following the study, we establish the main drivers of mobile commerce and the intensity of their influences. We have chosen to research the $\mathrm{m}$-commerce of the United States, given the existence of reliable statistical data at a macroeconomic level. Furthermore, the United States' economy is an essential vector of the global economy and innovation and a good predictor for future trends.

The originality of the research derives from the combined application of SEM and Artificial Neural Network on the set of data collected at the level of the United States to identify the main drivers of mobile commerce and the intensity of their influences. The structure of the paper is divided into six sections. After the introduction and literature review, we described the research variables, the selected sample, the hypotheses, and the research methods used. The following two sections show the research results and the discussions. The last section is dedicated to the conclusions.

\section{Theoretical Background}

Today, e-commerce is flourishing, as most companies that traditionally trade goods and services have focused on increasing their target customer array using online sales.

The important vectors that support the development of $\mathrm{m}$-commerce are information and telecommunications technologies, adding to the growing propensity of consumers for mobile devices in accessing online services, as accessibility and ubiquity of mobile technologies [16]. A study on the Internet and mobile devices, We Are Social and Hootsuite [17], shows that over half of the global population uses the Internet, and over two-thirds have a mobile device. Mobile devices take up almost half of the time spent on the Internet and are increasingly used for m-commerce, not just as a means of communication and 
entertainment. The growth of world trade over the last decade, coupled with the increase in speed and internet networks and the expansion of free $\mathrm{Wi}-\mathrm{Fi}$ in public places, has led to a strong upward trend in m-commerce [18]. COVID-19 has accelerated this trend due to imposed traffic restrictions and social distancing [15].

The literature has addressed a varied range of e-commerce matters, from technical issues, such as transaction security [19,20], data security, and software issues [21], to economic ones, such as marketing [22] and successful e-commerce factors [23]. The use of mobile devices for $\mathrm{m}$-commerce is another research topic addressed in scientific papers [24-27]. Other researchers have formulated an evaluation of this type of trade from the customer's perspective [28], assessing service quality [29]. The widespread use of smartphones and tablets, primarily in recent years, for several activities, including $\mathrm{m}$-commerce, has led to increased e-commerce.

Despite all the efforts of researchers in recent years, there is a gap in the literature on $\mathrm{m}$-commerce. Most research focuses on e-commerce as a whole, focusing less on the peculiarities of $\mathrm{m}$-commerce. Starting from the conclusions of the analyses of Pousttchi et al. [30] and Tang [31], we found that certain features and trends of $\mathrm{m}$-commerce are captured only in a few types of research so far, not taking into account, for example, the real-time interactions, social aspects, mobility, and accessibility offered by mobile devices. Moreover, Pousttchi et al. [30] and Tang [31] concluded that most scientific papers in this area are based on previously developed methodologies. Tang [31] and Saritas et al. [30] (p. 1556) pointed out that "research flows on m-commerce are still very inconsistent and fragmented".

Duch-Brown et al. [32] review the benefits that e-commerce generates for companies that choose this distribution channel for products and services. They point out that $\mathrm{m}$ commerce provides companies with a channel to promote and distribute their products and services more efficiently, providing consumer analysis and feedback tools. In addition, m-commerce facilitates a greater degree of product differentiation. Studying the literature, we observed that the implementation of e-commerce, especially m-commerce, positively influences the performance of companies and economic performance in general [33-41]. Sobihah et al. [37] and Sobihah and Lukman [42] analyzed multiple regressions to demonstrate that e-commerce and $\mathrm{m}$-commerce significantly influence organizational performance. Zhu and Kraemer [33] illustrate that those companies with a higher degree of e-commerce benefit from improved performance. The relationship between the implementation of e-commerce and the organizational performance of tourism companies is studied by various authors [39-41], which indicates a positive relationship.

Other authors $[35,36]$ show that technological resources are the key vectors of ecommerce and m-commerce, leading to better organization performance. For example, among the benefits of e-commerce, Jahanshahi et al. [43] list improving marketing processes, payment systems, productivity, and profits.

The COVID-19 health and economic crisis has changed the behavior of individuals in trade activities, and a predominant orientation of individuals who traditionally shopped (offline) towards e-commerce, and within e-commerce, to m-commerce can be observed [44]. The general behavior of e-commerce consumers changed significantly during the COVID19 pandemic. As a result, there was a sharp increase in the e-commerce share in total sales in the United States and an increase in the m-commerce share in e-commerce, which becomes predominant [13]. These changes will continue to some degree even when the COVID-19 pandemic is declared to be over. It can already be seen that the extension of the pandemic has led to a migration phenomenon from physical stores to online stores, and it is expected that some of the new customers will remain true to this kind of trade. Therefore, the e-commerce and m-commerce sectors will continue to grow faster than in the pre-pandemic period [15]. This increase in both e-commerce and $\mathrm{m}$-commerce had, over time, a positive impact on the gross domestic product within the U.S. However, the significant impact of e-commerce on GDP in 2020, when the COVID-19 pandemic was declared, did not influence GDP evolution because other economic sectors were affected by the health and economic crisis. Research into m-commerce developments is necessary at the 
micro-level (by investigating customer perceptions) and at the macro-level (by analyzing the trends of the m-commerce industry) to predict future outcomes and outline the way and time horizon in which $\mathrm{m}$-commerce will become predominant globally.

\section{Materials and Methods}

\subsection{Sample Selection and Variables}

To research the evolution of $\mathrm{m}$-commerce in the United States, we have chosen a longitudinal analysis, collecting chronological variables that illustrate total sales, e-commerce, m-commerce, internet usage rate, mobile device owners' rate, and gross domestic product (in absolute size and the form of indices). Data collected from multiple sources covered the period 2010-2020, and the year 2020 was influenced mainly by the health and economic COVID-19 crisis.

Total sales (T.sales), expressed in millions of U.S. dollars, represent a series of data adjusted for 2017, based on the Annual Retail Trade Survey. E-commerce (Ecomm), expressed in millions of U.S. dollars, represents sales of products or services made through an online system (Internet, m-commerce, extranet, Electronic Data Interchange network, electronic mail). We collected data on T.sales and Ecomm values from the United States Census Bureau $[45,46]$. Share of e-commerce (Sh.ecomm) represents the share of total sales by electronic means, obtained as a percentage of the variable Ecomm in T.sales.

M-commerce (Mcomm), expressed in millions of U.S. dollars, represents U.S. mobile retail commerce revenue. Share of $\mathrm{m}$-commerce (Sh.mcomm) represents the share of the total e-commerce achieved through applications on mobile devices, obtained as a percentage of the Mcomm variable in Ecomm. We collected Mcomm's and Sh.mcomm's values from Statista $[47,48]$.

Other tools commerce (OTcomm) is a variable obtained as a difference between ecommerce and $\mathrm{m}$-commerce and represents the total of transactions made by methods other than applications on mobile devices (such as the Internet, m-commerce, extranet, Electronic Data Interchange network, electronic mail). Sh.otcomm is the share of total e-commerce achieved through tools other than mobile applications, obtained as a percentage of the OTcomm variable in Ecomm.

In addition to the variables that illustrate the level of total sales, the e-commerce level, and the m-commerce level, we used the following two variables in the research to identify moderation effects or to mediate them: share of internet users (Sh.i_use), which represents the percentage of adults in the U.S. who use the internet, and share of mobile device owners (Sh.m_dev), which means the percentage of adults in the U.S. who own a mobile device. The data for the variable Sh.i_use were collected from Statista [49], and for the variable Sh.m_dev, data were collected from Pew Research Center [50].

To establish the influences found between the evolution of e-commerce, m-commerce, and economic growth, we used a variable illustrating economic growth: gross domestic product in research. Gross domestic product (GDP), measured in billions of U.S. dollars, includes the value of goods and services produced. The value of goods and services used as intermediate consumptions is deducted. GDP is a series of data adjusted for annual rates. Data on U.S. GDP values were collected from the U.S. Department of Commerce's Bureau of Economic Analysis [51]. Table 1 illustrates the data used in the research on the evolution of m-commerce. 
Table 1. Data collected for the research variables.

\begin{tabular}{|c|c|c|c|c|c|}
\hline Year & T.sales (Millions USD, \$) & Sh.ecomm (\%) & Sh.mcomm (\%) & Sh.i_Use (\%) & Sh.m_Dev (\%) \\
\hline 2011 & $3,818,048$ & 4.45 & 2.75 & 76 & 22 \\
\hline 2012 & $4,102,952$ & 4.88 & 7.75 & 79 & 35 \\
\hline 2013 & $4,302,229$ & 5.4 & 9.5 & 83 & 46 \\
\hline 2014 & $4,459,848$ & 5.86 & 15.95 & 84 & 55 \\
\hline 2015 & $4,641,927$ & 6.42 & 19.02 & 84 & 58 \\
\hline 2016 & $4,728,119$ & 7.15 & 23.93 & 84 & 69 \\
\hline 2017 & $4,848,213$ & 7.91 & 30.23 & 86 & 70 \\
\hline 2018 & $5,040,214$ & 8.79 & 35.26 & 88 & 73 \\
\hline 2019 & $5,253,037$ & 9.63 & 40.93 & 89 & 77 \\
\hline 2020 & $5,411,037$ & 10.69 & 46.46 & 90 & 81 \\
\hline
\end{tabular}

Source: Data collected from [45-51].

\subsection{Hypothesis and Methods}

Based on the purpose of this study, longitudinal analysis of U.S. m-commerce, we have formulated three hypotheses that address the relationships established between the evolution of m-commerce and the other variables selected in the research.

A first hypothesis (H1) concerns the correlations between the chronological evolutions of the total sales, e-commerce, $\mathrm{m}$-commerce, and gross domestic product: the Mcomm evolution correlates strongly and directly proportional to the variables Ecomm, T.sales, OTcomm, and GDP, with the rhythm of Mcomm's growth rate being more pronounced than the growth rates of Ecomm, T.sales, and GDP, which will lead to a predominant share of the total e-commerce of m-commerce.

A second hypothesis (H2) concerns the influences established between m-commerce and its specific variables selected in the research (total sales, e-commerce, share of Internet users, and share of mobile device owners): Mcomm supports a significant influence from the variables Ecomm and Sh.m_dev, and respectively, an average influence from the variables T.sales and Sh.i_use.

The third hypothesis (H3) investigates the mediation effects exerted by internet usage rate and mobile device owners' rate among m-commerce, e-commerce, and total sales: Sh.i_use exerts a strong mediation effect between the variables Ecomm and T.sale, and respectively, Sh.m_dev exerts a substantial mediation effect between the variables Mcomm and Ecomm.

To test the hypotheses, we used first the comparative analysis and the correlational analysis to highlight the close relationships between the variables based on the literature and to illustrate the evolution of mobile commerce before COVID-19 (2010-2019) and after COVID-19 (2020). Then, based on methodologies used by previous researchers [52-57] to test the hypotheses, we applied a combination of structural equation modeling and artificial neural network analysis. The combination of the two methods allowed the triangulation of data and the strengthening of research results.

To test the validity of the $\mathrm{H} 1$ hypothesis, we used correlational analysis and comparative analysis of the growth rates of the selected variables. For the analysis of bilateral correlations, we calculated the Pearson coefficient (1):

$$
r_{x y}=\frac{\sum_{i=1}^{n}\left(x_{i}-\bar{x}\right)\left(y_{i}-\bar{y}\right)}{\sqrt{\sum_{i=1}^{n}\left(x_{i}-\bar{x}\right)^{2}} \sqrt{\sum_{i=1}^{n}\left(y_{i}-\bar{y}\right)^{2}}}
$$

where $x, y$ are the selected variables, and $n$ is cases in the sample.

The growth rate of the variables Mcomm, Ecomm, T.sales, and GDP is calculated by reporting the difference between the absolute values of each year and the absolute values of the base year (2010) to the absolute values of the base year (2010):

$$
r_{\%}=\frac{x_{i}-x_{0}}{x_{0}}
$$


To test the validity of the $\mathrm{H} 2$ hypothesis, we used the analysis of artificial neural networks (ANN), which allows identifying the influences and importance of each variable within the analysis model [58]. We chose a model based on back-propagation of the multilayer perceptron type (MLP) to determine these influences (3):

$$
y=\left(\sum_{i=1}^{n} w_{i} x_{i}+b\right)=\varphi\left(W^{T} X+b\right)
$$

where $w, x$ are vectors of weights and inputs, $b$ is bias, and $\varphi$ is the activation function.

A hyperbolic tangent function (4) or a sigmoid function (5) can be used as an activation function of the hidden layer or the output layer:

$$
\begin{gathered}
f(n)=\frac{e^{n}-e^{-n}}{e^{n}+e^{-n}}=\frac{e^{2 n}-1}{e^{2 n}+1} \\
f(n)=\frac{1}{1+e^{-n}}=\frac{e^{n}}{e^{n}+1}
\end{gathered}
$$

where $n$ is the input variable and $f(n)$ is the output variable.

To test the validity of hypothesis H3, we applied structural equation modeling (SEM) (6), which allows determining the mediation effects among the selected variables. The formula used was the following [59]:

$$
\eta_{i}=\alpha_{\eta}+B \eta_{i}+\Gamma \xi_{i}+\zeta_{i}
$$

where $\eta, \xi$ are the endogenous and exogenous latent variables' vectors, $B$ is the matrix of regression coefficients relating the effects of the latent endogenous variables to each other, $\Gamma$ is the matrix of regression coefficients relating the effects of the latent exogenous variables to the latent endogenous variables, $\zeta$ is the vector of disturbances, and $i$ is cases in the sample.

\section{Results}

\begin{tabular}{|c|c|c|c|c|c|c|}
\hline & & Mcomm & T.sales & Ecomm & OT.comm & GDP \\
\hline \multirow{4}{*}{ Mcomm } & Correlation & 1 & $0.928^{* *}$ & $0.995^{* *}$ & $0.955^{* *}$ & $0.909 * *$ \\
\hline & Sig. (2-tailed) & & 0.000 & 0.000 & 0.000 & 0.000 \\
\hline & $\mathrm{N}$ & 11 & 11 & 11 & 11 & 11 \\
\hline & Correlation & $0.928^{* *}$ & 1 & $0.955^{* *}$ & $0.983^{* *}$ & 0.986 ** \\
\hline \multirow[t]{3}{*}{ T.sales } & Sig. (2-tailed) & 0.000 & & 0.000 & 0.000 & 0.000 \\
\hline & $\mathrm{N}$ & 11 & 11 & 11 & 11 & 11 \\
\hline & Correlation & $0.995 * *$ & $0.955 * *$ & 1 & $0.980 * *$ & $0.932 * *$ \\
\hline \multirow[t]{3}{*}{ Ecomm } & Sig. (2-tailed) & 0.000 & 0.000 & & 0.000 & 0.000 \\
\hline & $\mathrm{N}$ & 11 & 11 & 11 & 11 & 11 \\
\hline & Correlation & $0.955^{* *}$ & $0.983^{* *}$ & $0.980 * *$ & 1 & $0.952 * *$ \\
\hline \multirow[t]{2}{*}{ OT.comm } & Sig. (2-tailed) & 0.000 & 0.000 & 0.000 & & 0.000 \\
\hline & $\mathrm{N}$ & 11 & 11 & 11 & 11 & 11 \\
\hline \multirow{3}{*}{ GDP } & Correlation & $0.909^{* *}$ & $0.986^{* *}$ & $0.932 * *$ & $0.952^{* *}$ & 1 \\
\hline & Sig. (2-tailed) & 0.000 & 0.000 & 0.000 & 0.000 & \\
\hline & $\mathrm{N}$ & 11 & 11 & 11 & 11 & 11 \\
\hline
\end{tabular}

To test the validity of the $\mathrm{H} 1$ hypothesis, we first calculated the Pearson correlation coefficients between Mcomm, Ecomm, T.sales, OT-comm, and GDP (Table 2).

Table 2. Correlations between the variables that characterize sales and economic growth.

Source: Own calculations based on data collected from [45-51]; Note: ** -strong correlation.

Following the study of the correlation coefficients between the variables Mcomm, Ecomm, T.sales, OT-comm, and GDP, a significant positive correlation can be observed, with all variables recording a sustained increasing evolution in the period 2010-2020. In 
addition, Mcomm's growth rate is more pronounced than the growth rates of Ecomm, T.sales, and GDP, and will increase given the background of the health crisis generated by COVID-19 and its consequences. In Table 3, we have shown the growth rates of the variables Mcomm, Ecomm, and T.sales.

Table 3. The growth rates of variables that characterize sales and economic growth (\%).

\begin{tabular}{ccccc}
\hline & T.sales & Ecomm & Mcomm & GDP \\
\hline 2011 & 7.46 & 17.93 & 232.35 & 3.67 \\
2012 & 12.68 & 36.65 & 372.06 & 8.04 \\
2013 & 16.81 & 53.93 & 792.61 & 11.96 \\
2014 & 21.58 & 75.37 & 1112.76 & 16.91 \\
2015 & 23.84 & 99.06 & 1632.14 & 21.65 \\
2016 & 26.98 & 125.67 & 2380.73 & 25.03 \\
2017 & 32.01 & 160.84 & 3244.44 & 30.36 \\
2018 & 37.58 & 197.85 & 4333.08 & 37.49 \\
2019 & 41.72 & 240.45 & 5651.98 & 42.96 \\
2020 & 46.20 & 346.92 & 8203.97 & 39.65 \\
\hline
\end{tabular}

Source: Own calculations based on data collected from [45-51].

Table 3 shows the growth rate of e-commerce much higher than the total sales and the rapid growth rate of $\mathrm{m}$-commerce, which in just ten years has exceeded all expectations. The strongly upward developments of $\mathrm{m}$-commerce, against the background of the increasing penetration level of mobile devices, will increase their use for purchases of goods and services and a predominant share of $\mathrm{m}$-commerce in total e-commerce. This phenomenon is illustrated in Figure 1.

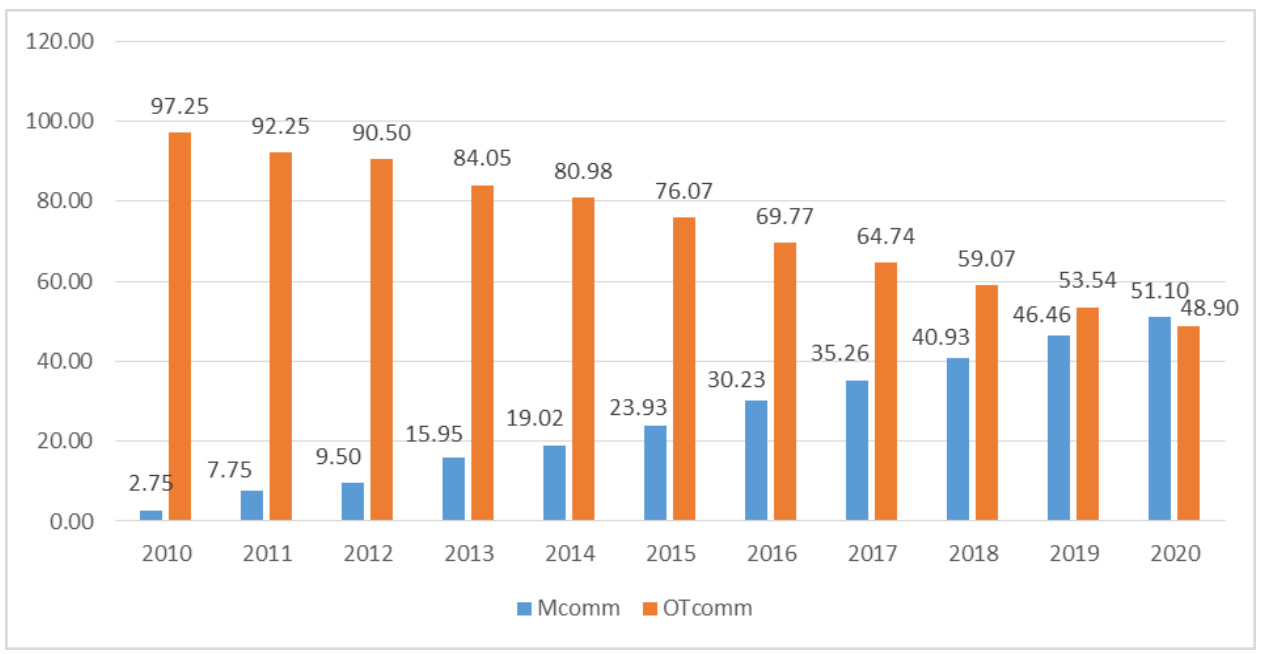

Figure 1. Comparative evolution of m-commerce and other tools of commerce. Source: developed by authors.

Following the research, we validated the first hypothesis (H1). Mcomm's evolution correlates strongly and directly proportional to Ecomm, T.sales, OTcomm, and GDP. Mcomm's growth rate is stronger than Ecomm's, T.sales', and GDP's growth rates. This will determine, especially on the background of traffic restrictions and social distancing rules generated by the COVID-19 pandemic, the predominance of $\mathrm{m}$-commerce in total e-commerce, and the increase in the share of e-commerce in total sales. Similarly, the authors of [13] show that in the context of the global transformations generated by the COVID-19 pandemic, the global economy has reduced cash flows, with trade transitioning to the online environment, which has revealed the growing influence of the internet on global economic processes. First, the immobility generated by the declared lockdowns 
around the globe, traffic restrictions, and social distancing rules led the consumer to turn to the internet, and chiefly to mobile solutions, to make purchases of products and services.

The expansion of $\mathrm{m}$-commerce was helped in 2020 by the health crisis generated by the COVID-19 pandemic through physical distancing restrictions [15]. These restrictions have led many consumers to turn to e-commerce and especially to m-commerce due to the ease of use of mobile devices. The convenience of using these devices and the speed of mobile transactions have led more and more customers, especially those in Generation $Z$ and Generation X, to opt for this type of e-commerce [60].

To test the validity of the $\mathrm{H} 2$ hypothesis, we used the analysis of Artificial Neural Networks (ANN), a multilayer perceptron (MLP) model, which allows identifying the influences and importance of each variable within the model. Total sales (T.sales), ecommerce (Ecomm), the share of internet users (sh.i_use), and the share of mobile device owners (Sh.m_dev) are defined as input variables. These influence the hidden layer that represents the inclination of individuals to use mobile applications to make purchases of goods and services. The hidden layer exerts a significant impact on the output variable that illustrates m-commerce (Mcomm). As the activation function of the hidden layer, we used a tangent hyperbolic tangent function, and as the activation function of the output layer, we used a sigmoid function. The bias that acts on the hidden layer represents exogenous factors that concern the transaction's subject: income, age, lifestyle, occupation, social environment, conceptions, and perceptions. The bias acting on the output layer represents exogenous factors, such as economic growth and the evolution of the IT\&C industry. Figure 2 describes the synaptic connections (meaning and intensity) between the analyzed variables.

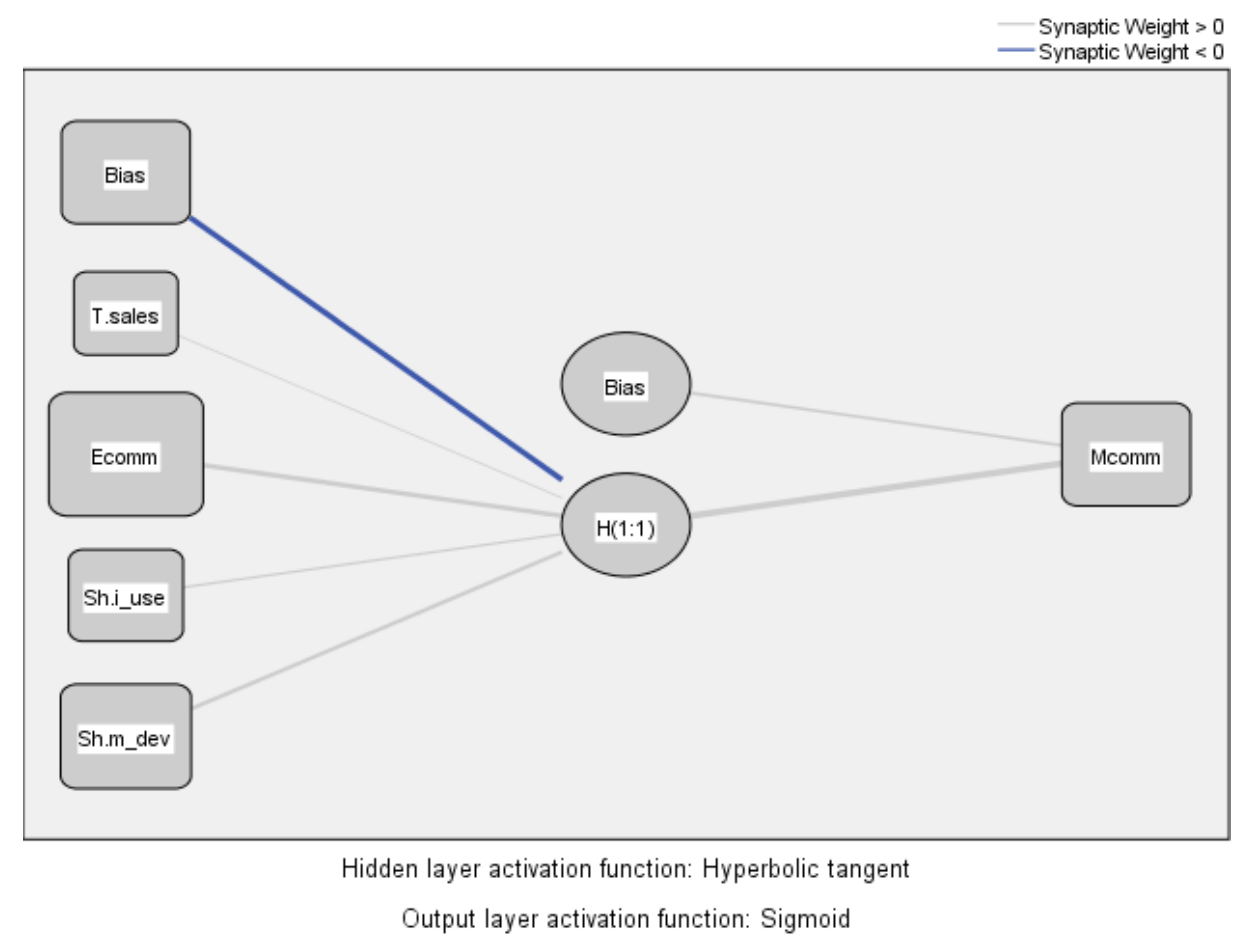

Figure 2. MLP model for identifying the influences on m-commerce. Source: developed using SPSS v.20.

The error resulting from model testing is 0.023 , while the error resulting from training is 0.164 . The rescaling method used was data standardization. Table 4 shows the predictors of the MLP model. 
Table 4. The predictors of the MLP model.

\begin{tabular}{|c|c|c|c|}
\hline \multirow{2}{*}{\multicolumn{2}{|c|}{ Predictor }} & \multicolumn{2}{|c|}{ Predicted } \\
\hline & & $\begin{array}{c}\text { Hidden Layer } 1 \\
\text { H (1:1) }\end{array}$ & $\begin{array}{c}\text { Output Layer } \\
\text { Mcomm }\end{array}$ \\
\hline \multirow{6}{*}{ Input Layer } & & & \\
\hline & (Dias) & $-0.3 / 9$ & \\
\hline & T.sales & 0.014 & \\
\hline & Ecomm & 0.484 & \\
\hline & Sh.i_use & 0.134 & \\
\hline & Sh.m_dev & 0.356 & \\
\hline \multirow{2}{*}{ Hidden Layer 1} & (Bias) & & 0.250 \\
\hline & $\mathrm{H}(1: 1)$ & & 2.798 \\
\hline
\end{tabular}

Source: developed using SPSS v.20.

The data analysis showed a significant influence of Ecomm and Sh.m_dev and a relatively small impact of the variables T.sales and Sh.i_use through the hidden layer represented by the inclination of individuals to use applications within mobile devices to make purchases of goods and services. Higher levels of the variables total sales, ecommerce, internet users' share, and mobile device owners' share cause a positive change in m-commerce levels. The external influences represented by the bias exerted on the hidden layer are pretty consistent because the exogenous factors regarding the subject of the transaction have had consistent adverse effects on m-commerce, due to the mentalities and prejudices still present among individuals concerning $\mathrm{m}$-commerce and e-commerce. On the other hand, external influences represented by the bias exerted on the output layer are positive, indicating a directly proportional relationship with m-commerce. Following the research of the $\mathrm{H} 2$ hypothesis, we confirmed its validity, which shows a more substantial influence on the $\mathrm{m}$-commerce of the variables share of mobile device owners and e-commerce and a slight influence of the variables total sales and share of internet users. However, the increase in the share of individuals using the internet and the increase in the share of individuals owning a mobile phone are significant determinants for the evolution of $\mathrm{m}$-commerce and the general development of e-commerce. This fact also emerges from Figure 3, which shows the levels of absolute and normalized importance of the input variables concerning $\mathrm{m}$-commerce.

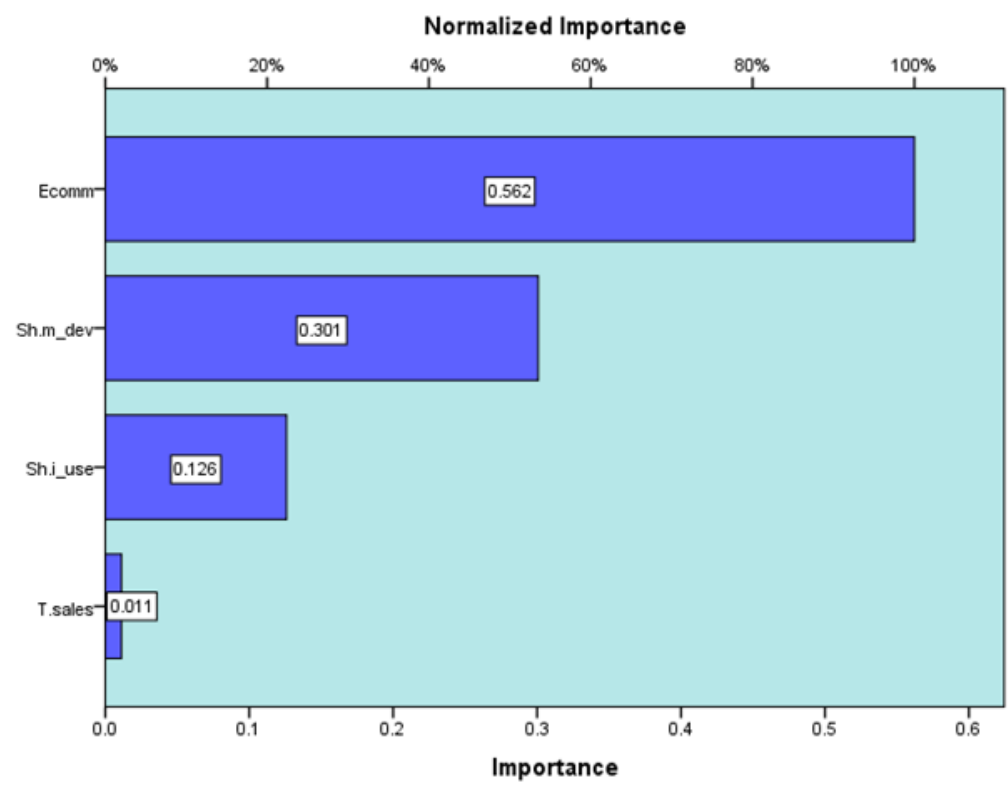

Figure 3. Importance of variables from the MLP model. Source: developed using SPSS v.20. 
The result of the $\mathrm{H} 2$ hypothesis investigation is in line with the results of other studies showing the influence of the increase in the share of mobile device owners and the evolution of e-commerce in general, due to the rise in the number of individuals accessing the Internet [61-64].

For the research of the H3 hypothesis, we used structural equation modeling (SEM), establishing the direct and indirect relationships between the researched variables. The direct and indirect effects of the e-commerce variable on total sales and the m-commerce variable on e-commerce were calculated using the share of internet users, and respectively, the share of mobile device owners, as moderating variables. Figure 4 illustrates standardized estimations of relationships among model variables to identify mediation effects. The selected model defines four observed variables (Ecomm, T.sale, Sh.i_use, Sh.m_dev) as endogenous, one observed variable (Mcomm) as exogenous, and four unobserved exogenous variables (s, i1, i2, i3) which influence the endogenous variables.

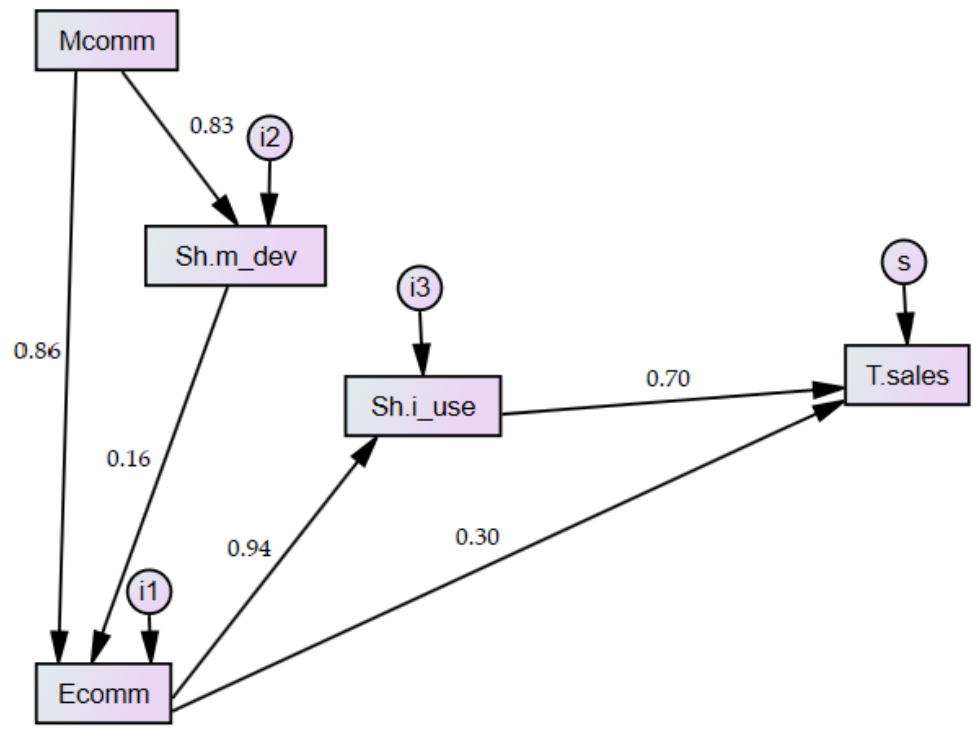

Figure 4. Diagram of relationships in SEM concerning m-commerce. Source: developed using AMOS for SPSS v20.

Within the model, we used the method of estimating maximum likelihood. Chi-square registered the value 24.678, with four degrees of freedom and a probability level $=0.000$. Table 5 shows the direct, indirect, and total standardized effects between model variables.

Table 5. Direct and indirect standardized effects.

\begin{tabular}{|c|c|c|c|c|}
\hline \multicolumn{5}{|c|}{ Total Standardized Effects } \\
\hline & Mcomm & Sh.m_dev & Ecomm & Sh.i_use \\
\hline Sh.m_dev & 0.832 & 0.000 & 0.000 & 0.000 \\
\hline Ecomm & 0.995 & 0.165 & 0.000 & 0.000 \\
\hline Sh.i_use & 0.931 & 0.154 & 0.936 & 0.000 \\
\hline T.sales & 0.951 & 0.157 & 0.955 & 0.702 \\
\hline \multicolumn{5}{|c|}{ Direct Standardized Effects } \\
\hline & Mcomm & Sh.m_dev & Ecomm & Sh.i_use \\
\hline Sh.m_dev & 0.832 & 0.000 & 0.000 & 0.000 \\
\hline Ecomm & 0.858 & 0.165 & 0.000 & 0.000 \\
\hline Sh.i_use & 0.000 & 0.000 & 0.936 & 0.000 \\
\hline T.sales & 0.000 & 0.000 & 0.298 & 0.702 \\
\hline \multicolumn{5}{|c|}{ Indirect Standardized Effects } \\
\hline & Mcomm & Sh.m_dev & Ecomm & Sh.i_use \\
\hline Sh.m_dev & 0.000 & 0.000 & 0.000 & 0.000 \\
\hline Ecomm & 0.137 & 0.000 & 0.000 & 0.000 \\
\hline Sh.i_use & 0.931 & 0.154 & 0.000 & 0.000 \\
\hline T.sales & 0.951 & 0.157 & 0.657 & 0.000 \\
\hline
\end{tabular}


Analyzing the relations in Figure 4 and the values in Table 5, we can identify strong mediation relations between the variables Ecomm and T.sales exerted by the variable Sh.i_use as a mediation factor. The value of the indirect effect is 0.657 , while the direct impact has a value of only 0.298 , resulting in a standardized total effect of 0.955 . The identified mediation effect indicates that the higher the share of those who use the Internet, the more individuals who will use the Internet to purchase goods and services. As a result, it will increase the share of e-commerce in total sales, to the detriment of traditional trade methods.

The mediation effect exerted by the variable Sh.m_dev in the relationship between Mcomm and Ecomm is relatively weak, registering only 0.137 . However, the direct impact recorded between the variables has a value of 0.858 , making the total standardized effect report a high value $(0.995)$. This weak mediation relationship means that simply owning a mobile device is not a determining factor in the option for $\mathrm{m}$-commerce, and there are other exogenous factors related to the subject of the transaction: income, age, lifestyle, occupation, social environment, concepts, and perceptions.

Analyzing the model of structural equations for selected variables, we can also identify a mediation relationship, which is obvious, exerted by the variable Ecomm in the relationship established between the variables Mcomm and T.sales. Following the research of the validity of the $\mathrm{H} 3$ hypothesis, the result was a partial validation, identifying strong mediation effects exerted by the variable Sh.i_use in the relationship between the variables Ecomm and T.sales, and weak effects exerted by the variable Sh.m_dev in the relationship between the variables Mcomm and Ecomm. Like other researchers, we have concluded that $\mathrm{m}$-commerce and e-commerce are essential channels of trade, which are increasingly replacing traditional forms of commerce [15,60,61].

\section{Discussion}

M-commerce is the simplest form of e-commerce, as mobile devices are available to individuals all the time, and applications are straightforward to use. Moreover, individuals access mobile devices more often than computers for practical reasons, regardless of where they are. Today, mobile use provides comfort and convenience in consumer transactions, affording them a pleasant experience, which is then used as an excuse to turn into a new consumer habit. Our research (the results of the $\mathrm{H} 1$ hypothesis research) and other previous research $[13,15,44]$ have shown that this trend of using $\mathrm{m}$-commerce has increased in recent years. Moreover, given the restrictions on movement and the rules of social distancing generated by the COVID-19 pandemic, this trend has risen further [65].

Globally, there is an indisputable social phenomenon that targets the time spent by individuals in the company of their mobile devices. In addition to the communication function and the entertainment function, the use as a tool for purchasing goods and services is among mobile devices' most frequently used functions. Furthermore, mobile devices have increased the accessibility and mobility of information, offering the advantages of convenience, speed, and ease of use [66]. Our research (the results of the $\mathrm{H} 2$ hypothesis research) showed that the main macro-factors that led to an increase in $\mathrm{m}$-commerce were primarily the expansion of e-commerce, including in the COVID-19 crisis context [67], and secondly, the share of mobile device owners that has seen sustained growth in recent years. These factors, along with the increasing share of the number of Internet users and the expansion of sales, have led to an increase in the tendency of individuals to use mobile applications to make purchases of goods and services.

As the exponential expansion of wireless networks and mobile devices has taken place, consumers have paid increasing attention to m-commerce [61]. As a result, mobile device users and the mobile technology market have sharply increased in recent years. Furthermore, 4G communication technologies and 5G networks have attracted even more users of mobile devices interested in accessing the internet for various purposes [61,63-67]. Our research (the results of the $\mathrm{H} 3$ hypothesis research) has shown that the increase in the share of Internet users is a significant mediating variable, which leads to a rise in the share of e-commerce and $\mathrm{m}$-commerce in total sales. On the other hand, the variable illustrating 
the share of mobile device owners exerted relatively low mediation effects between the $\mathrm{m}$-commerce and e-commerce variables. However, these mediation effects will intensify as Generation $Z$ enters the labor market and will have income, given the predominant inclination of this segment of the population towards $m$-commerce $[60,61]$. Thus, the m-commerce environment has generated new patterns and facilitated the development of new technologies in e-commerce.

\section{Conclusions, Limitations, and Further Research}

The fourth industrial revolution has generated technological advances that global companies cannot ignore. Technological developments that have characterized recent years in terms of wireless technologies and mobile devices have led to a change in the behavior of individuals in general, but also a change in consumption habits. Today, many individuals own a mobile phone or tablet connected to the internet at any time, which makes mobile commerce accessible to most individuals, regardless of space and time, with the advent of m-commerce. The continuous expansion, both in mobile devices and mobile applications, has determined companies to raise awareness of the potential of $\mathrm{m}$-commerce. M-commerce and e-commerce are channels of trading with a solid upward trend, which may rapidly become prevalent in the context of technological developments.

In this paper, we carried out a longitudinal analysis of m-commerce developments and competitiveness at the macro-level (at the United States level). After analyzing and interpreting the results, we can say that, due to the ubiquity and accessibility of mobile devices in consumers' lives, and the improvement of the quality and quantity of mobile communications, $\mathrm{m}$-commerce will dominate e-commerce and play a significant role in total sales.

As limitations of our research, it is worth mentioning the scarcity of data at the macrolevel regarding $\mathrm{m}$-commerce developments and their determinants. The longitudinal analysis included eleven years as m-commerce became relevant, especially from the second decade of the 21st century. Another limitation emerged from the sample selection (United States data). Nevertheless, we have chosen to research the m-commerce of the United States, given the existence of reliable statistical data at a macroeconomic level. Potential future research directions might expand the study to a more significant number of drivers and antecedents, and to multiple variables with a mediation or moderation role, influencing $\mathrm{m}$-commerce relations with other types of commerce or total sales evolution. Additionally, as data become available, $\mathrm{m}$-commerce research can expand globally. Our paper has made a modest contribution to the macro-level analytical analysis of m-commerce developments, proposing a research model that considers multiple macro-variables that influence $\mathrm{m}$ commerce and are influenced by m-commerce. M-commerce actors can use the model to better understand the vectors that drive m-commerce growth and invest more in the approaches highlighted: increasing internet speed, expanding 5G and Wi-Fi networks, and increasing accessibility and trust in mobile devices and applications.

Author Contributions: Conceptualization, A.A.V. and C.G.B.; methodology, A.A.V. and C.G.B.; validation, A.A.V. and C.G.B.; formal analysis, A.A.V. and C.G.B.; investigation, A.A.V. and C.G.B.; resources, A.A.V. and C.G.B.; data curation, A.A.V.; writing-original draft preparation, A.A.V. and C.G.B.; writing-review and editing, A.A.V. and C.G.B.; visualization, A.A.V. and C.G.B.; supervision, C.G.B.; project administration, A.A.V. All authors have read and agreed to the published version of the manuscript.

Funding: This research received no external funding.

Institutional Review Board Statement: Not applicable.

Informed Consent Statement: Not applicable.

Data Availability Statement: Data used in this paper are available at following sources: United States Census Bureau (USCB). Estimated Annual U.S. Retail Trade Sales-Total and E-Commerce, https: / / www2.census.gov/programs-surveys/arts/tables/2019/ecommerce.xlsx (accessed on 26 July 2021); 
United States Census Bureau (USCB). Estimated Quarterly U.S. Retail Sales: Total and E-commerce, https:/ / www.census.gov/retail/mrts/www/data/excel/21q1table1.xls (accessed on 26 July 2021); Statista. U.S. Mobile Retail Commerce Revenue 2013-2020, https:/ / www.statista.com/statistics / 249855 /mobile-retail-commerce-revenue-in-the-united-states (accessed on 26 July 2021)/; Fulgoni, G. Mobile and the Path to Purchase, https:/ / www.slideshare.net/Planimedia/state-of-themobilemarketfinal? from_action=save (accessed on 26 July 2021); Statista. Share of Adults in The United States Who Use the Internet, https: / www.statista.com/statistics /185700/percentage-of-adult-internet-users-in-theunited-states-since-2000/ (accessed on 26 July 2021); Pew Research Center (PRC). Mobile Fact Sheet, https:/ /www.pewresearch.org/internet/fact-sheet/mobile/ (accessed on 26 July 2021); Bureau of Economic Analysis (BEA). National Income and Product Accounts. Table 1.1.4. Price Indexes for Gross Domestic Product; Table 1.1.5. Gross Domestic Product, https://apps.bea.gov/iTable/iTable.cfm?reqid= $19 \&$ step $=2 \#$ reqid $=19 \&$ step $=2 \&$ isuri $=1 \& 1921=$ survey (accessed on 26 July 2021).

Conflicts of Interest: The authors declare no conflict of interest.

\section{References}

1. eMarketer (Ed.) Worldwide Ecommerce will Approach \$5 Trillion This Year. Available online: https: / / www.emarketer.com/ content/worldwide-ecommerce-will-approach-5-trillion-this-year?ecid=NL1014 (accessed on 10 May 2021).

2. Wurmser, Y. Mobile Shopping Gains Are Likely to Stick in the Future. Available online: https://www.emarketer.com/content/ mobile-shopping-gains-likely-stick-future (accessed on 7 April 2021).

3. De Best, R. Mobile Payments Worldwide-Statistics \& Facts. Available online: https://www.statista.com/topics/4872/mobilepayments-worldwide/ (accessed on 16 March 2021).

4. Holmes, A.; Byrne, A.; Rowley, J. Mobile shopping behaviour: Insights into attitudes, shopping process involvement and location. Int. J. Retail. Distrib. Manag. 2014, 42, 25-39. [CrossRef]

5. Kuo, T.; Tsai, G.Y.; Lu, I.Y.; Chang, J.S. Relationships among service quality, customer satisfaction and customer loyalty: A case study on mobile shopping APPs. In Proceedings of the 17th Asia Pacific Industrial Engineering and Management System Conference, Taipei, Taiwan, 7-10 December 2016; pp. 7-10.

6. Marinkovic, V.; Kalinic, Z. Antecedents of customer satisfaction in mobile commerce. Online Inf. Rev. 2017, 41, 138-154. [CrossRef]

7. Chung, K.C. Transaction Utility Perspective of Customer Satisfaction towards M-Commerce in Taiwan. In Proceedings of the 2019 5th International Conference on E-business and Mobile Commerce-ICEMC 2019, Taichung, Taiwan, 22-24 May 2019; Association for Computing Machinery (ACM): New York, NY, USA, 2019; pp. 1-5. [CrossRef]

8. Kalinic, Z.; Marinkovic, V.; Djordjevic, A.; Liebana-Cabanillas, F. What drives customer satisfaction and word of mouth in mobile commerce services? A UTAUT2-based analytical approach. J. Enterp. Inf. Manag. 2020, 33, 71-94. [CrossRef]

9. Thakur, R. The moderating role of customer engagement experiences in customer satisfaction-loyalty relationship. Eur. J. Mark. 2019, 53, 1278-1310. [CrossRef]

10. Marinao-Artigas, E.; Barajas-Portas, K. Precedents of the satisfaction of mobile shoppers. A cross-country analysis. Electron. Commer. Res. Appl. 2020, 39, 100919. [CrossRef]

11. Ghose, A.; Han, S.P.; Xu, K. Mobile commerce in the new tablet economy. In Proceedings of the International Conference on Information Systems, ICIS 2013, Milano, Italy, 15-18 December 2013; pp. 2591-2608.

12. Seth, A.; Osei, A.M.; Dzaka, D. Re-Defining the Future of Commerce: Mobile Commerce and the Emergence of Sixth Sense Technology. Sing. J. Bus. Econ. Manag. Stud. 2015, 3, 1-8. [CrossRef]

13. Dumanska, I.; Hrytsyna, L.; Kharun, O.; Matviiets, O. E-commerce and M-commerce as Global Trends of International Trade Caused by the Covid-19 Pandemic. WSEAS. Trans. Environ. Dev. 2021, 17, 386-397. [CrossRef]

14. Kim, E.-A. Social Distancing and Public Health Guidelines at Workplaces in Korea: Responses to Coronavirus Disease-19. Saf. Health Work 2020, 11, 275-283. [CrossRef]

15. Sardjono, W.; Selviyanti, E.; Mukhlis, M.; Tohir, M. Global issues: Utilization of e-commerce and increased use of mobile commerce application as a result of the covid-19 pandemic. J. Phys. Conf. Ser. 2021, 1832, 012024. [CrossRef]

16. Saritas, O.; Bakhtin, P.; Kuzminov, I.; Khabirova, E. Big data augmented business trend identification: The case of mobile commerce. Scientometrics 2021, 5, 1-27. [CrossRef]

17. We Are Social and Hootsuite. Global Digital Report. Available online: https://wearesocial.com/blog/2019/01/digital-2019 -global-internet-use-accelerates (accessed on 23 June 2021).

18. Hew, J.J. Hall of fame for mobile commerce and its applications: A bibliometric evaluation of a decade and a half (2000-2015). Telemat. Inform. 2017, 34, 43-66. [CrossRef]

19. Kaushik, D.; Gupta, A.; Gupta, S. E-Commerce Security Challenges: A Review. In Proceedings of the International Conference on Innovative Computing \& Communications (ICICC) 2020, New Delhi, India, 21-23 February 2020. [CrossRef]

20. Khan, S.W. Cyber security issues and challenges in E-commerce. In Proceedings of the 10th International Conference on Digital Strategies for Organizational Success, Gwalior, India, 5-7 January 2019. [CrossRef]

21. Kaabi, S.; Jallouli, J. Overview of E-commerce Technologies, Data Analysis Capabilities and Marketing Knowledge. In Proceedings of the International Conference on Digital Economy; Springer: Cham, Switzerland, 2019. [CrossRef] 
22. Katsikeas, C.; Leonidou, L.; Zeriti, A. Revisiting international marketing strategy in a digital era. Int. Mark. Rev. 2019, 37, 405-424. [CrossRef]

23. Fouskas, K.; Tsitiridou, O.-G.; Chatziharisto, C. A Systematic Literature Review on E-Commerce Success Factors. In Strategic Innovative Marketing and Tourism; Springer: Cham, Switzerland, 2020. [CrossRef]

24. Zarmpou, T.; Saprikis, V.; Markos, A.; Vlachopoulou, M. Modeling users' acceptance of mobile services. Electr. Comm. Res. 2012, 12, 225-248. [CrossRef]

25. Ozturk, O.; Rizvanoglu, K. M-Commerce usability: An explorative study on turkish private shopping apps and mobile sites. In Proceedings of the International Conference of Design, User Experience, and Usability; Springer: Berlin/Heidelberg, Germany, 2013; pp. 623-630. [CrossRef]

26. Jakimoski, K. Analysis of the Usability of Mcommerce Applications. Int. J. U Eser. Sci. Tech. 2014, 7, 13-20. [CrossRef]

27. Sanz, L.F.; Pérez, J.G.; Martinez, C.A.; Misra, S. Analysis of Mobile Commerce in the SMEs of the European Union. Tech. Gaz. 2020, 27, 2062-2071. [CrossRef]

28. Wu, J.H.; Wang, Y.M. Development of a tool for selecting mobile shopping site: A customer perspective. Electr. Comm. Res. Appl. 2006, 5, 192-200. [CrossRef]

29. Nilashi, M.; Ibrahim, O.; Mirabi, V.R.; Ebrahimi, L.; Zare, M. The role of Security, Design and Content factors on customer trust in mobile commerce. J. Retail. Cons. Serv. 2015, 26, 57-69. [CrossRef]

30. Pousttchi, K.; Tilson, D.; Lyytinen, K.; Hufenbach, Y. Introduction to the special issue on mobile commerce: Mobile commerce research Yesterday, Today, Tomorrow-What remains to be done? Int. J. Electr. Comm. 2015, 19, 1-20. [CrossRef]

31. Tang, A.K. A systematic literature review and analysis on mobile apps in m-commerce: Implications for future research. Electr. Comm. Res. Appl. 2019, 37, 100885. [CrossRef]

32. Duch-Brown, N.; Grzybowski, L.; Romahn, A.; Verboven, F. The impact of online sales on consumers and firms. Evidence from consumer electronics. Int. J. Ind. Organ. 2017, 20, 30-62. [CrossRef]

33. Zhu, K.; Kraemer, K.L. Post-adoption variations in usage and value of e-business by organizations: Cross-country evidence from the retail industry. Inf. Syst. Res. 2005, 16, 61-84. [CrossRef]

34. Oh, L.B.; Teo, H.H.; Sambamurthy, V. The Effects of Retail Channel Integration Through the Use of InformationnTechnologies on Firm Performance. J. Oper. Manag. 2012, 30, 368-381. [CrossRef]

35. Jehangir, M.; Dominic, P.D.D.; Downe, A.G.; Naseebullah. Technology Resources and E-Commerce Impact on Business Performance. Commun. Comput. Inf. Sci. 2011, 189, 440-447.

36. Kareem, T.S.; Owomoyela, S.K.; Oyebamiji, F.F. Electronic Commerce and Business Performance: An Empirical Investigation of Business Organizations. Int. J. Acad. Res. Bus. Soc. Sci. 2014, 4, 215-223.

37. Sobihah, A.H.M.; Munir, A.; Embat, M.S.; Aziz, W.A.; Amin, B.W.M.; Muda, M.S. The Relationship between E-Commerce Adoption and Organization Performance. Int. J. Bus. Manag. 2014, 9, 56-62. [CrossRef]

38. Falk, M.; Hagsten, E. E-commerce trends, and impacts across Europe. Int. J. Prod. Econ. 2015, 170, 357-369. [CrossRef]

39. Salwani, M.I.; Marthandan, G.; Norzaidi, M.D.; Chong, S.C. E-commerce usage and business performance in the Malaysian tourism sector: Empirical analysis. Inf. Manag. Comput. Secur. 2009, 17, 166-185. [CrossRef]

40. Fuchs, M.; Hopken, W.; Foger, A.; Kunz, M. E-Business Readiness, Intensity, and Impact: An Austrian Destination Management. Organ. Study J. Travel Res. 2010, 49, 165-178. [CrossRef]

41. Changa, B.Y.; Magobeb, M.J.; Kimc, Y.B. E-commerce applications in the tourism industry: A Tanzania case study. South Afr. J. Bus. Manag. 2015, 46, 53-64. [CrossRef]

42. Sobihah, A.H.M.; Lukman, Z.M. Organizational Culture Mediate Between E-Commerce Adoption and Hotel Performance. Mediterr. J. Soc. Sci. 2015, 6, 61-66. [CrossRef]

43. Jahanshahi, A.A.; Razaei, M.; Nawaser, K.; Ranjbar, V.; Pitamber, B.K. Analyzing the effects of electronic commerce on organizational performance: Evidence from small and medium enterprises. Afr. J. Bus. Manag. 2012, 6, 6486-6496.

44. Pantelimon, F.V.; Georgescu, T.M.; Posedaru, B.S. The Impact of Mobile e-Commerce on GDP: A Comparative Analysis between Romania and Germany and how Covid-19. Influences the e-Commerce activity Worldwide. Info Econ. 2020, 24, 27-41. [CrossRef]

45. United States Census Bureau (USCB). Estimated Annual U.S. Retail Trade Sales-Total and E-Commerce. Available online: https:/ / www2.census.gov / programs-surveys/arts/tables/2019/ecommerce.xlsx (accessed on 24 May 2021).

46. United States Census Bureau (USCB). Estimated Quarterly U.S. Retail Sales: Total and E-commerce. Available online: https: //www.census.gov/retail/mrts/www/data/excel/21q1table1.xls (accessed on 24 May 2021).

47. Statista. U.S. Mobile Retail Commerce Revenue 2013-2020. Available online: https://www.statista.com/statistics/249855 /mobile-retail-commerce-revenue-in-the-united-states / (accessed on 26 May 2021).

48. Fulgoni, G. Mobile and the Path to Purchase. Available online: https://www.slideshare.net/Planimedia/state-ofthemobilemarketfinal?from_action=save (accessed on 27 May 2021).

49. Statista. Share of Adults in The United States Who Use the Internet. Available online: https://www.statista.com/statistics/1857 00/percentage-of-adult-internet-users-in-the-united-states-since-2000/ (accessed on 26 May 2021).

50. Pew Research Center (PRC). Mobile Fact Sheet. Available online: https://www.pewresearch.org/internet/fact-sheet/mobile/ (accessed on 30 May 2021). 
51. Bureau of Economic Analysis (BEA). National Income and Product Accounts. Table 1.1.4. Price Indexes for Gross Domestic Product; Table 1.1.5. Gross Domestic Product. Available online: https:/ /apps.bea.gov/iTable/iTable.cfm?reqid=19\&step=2\# reqid $=19 \&$ step $=2 \&$ isuri $=1 \& 1921=$ survey (accessed on 29 May 2021).

52. Liébana-Cabanillas, F.; Marinkovic, V.; Ramos de Luna, I.; Kalinic, Z. Predicting the determinants of mobile payment acceptance: A hybrid SEM-neural network approach. Tech. Forecast. Soc. Chang. 2018, 129, 117-130. [CrossRef]

53. Abubakar, A.M. Using hybrid SEM-Artificial intelligence: Approach to examine the nexus between burnout, generation, career, life and job satisfaction. Pers. Rev. 2020, 29, 67-86. [CrossRef]

54. Yakubu, M.N.; Dasuki, S.I.; Abubakar, A.M.; Kah, M.M. Determinants of learning management systems adoption in Nigeria: A hybrid SEM and artificial neural network approach. Ed. Inf. Tech. 2020, 25, 3515-3539. [CrossRef]

55. Oday, A.; Ozturen, A.; Ilkan, M.; Abubakar, A.M. Do eReferral, eWOM, familiarity and cultural distance predict enrollment intention? An application of an artificial intelligence technique. J. Hosp. Tour. Tech. 2021, 12, 471-488. [CrossRef]

56. Kalinić, Z.; Marinković, V.; Kalinić, L.; Liébana-Cabanillas, F. Neural network modeling of consumer satisfaction in mobile commerce: An empirical analysis. Exp. Syst. Appl. 2021, 175, 114803. [CrossRef]

57. Akgül, Y. An Integrated SEM-Neural Network Approach for Predicting Mobile Banking Determinants of Adoption in Turkey. In Applications of Artificial Neural Networks for Nonlinear Data; Patel, H.A., Kumar, V.S., Eds.; IGI Global: Hershey, PA, USA, 2021; pp. 154-179.

58. Hew, T.-S.; Leong, L.-Y.; Ooi, K.-B.; Chong, A.Y.-L. Predicting Drivers of Mobile Entertainment Adoption: A Two-Stage SEMArtificial-Neural-Network Analysis. J. Comput. Inf. Syst. 2016, 56, 352-370. [CrossRef]

59. Bollen, K.A.; Noble, M.D. Structural equation models and the quantification of behavior. Proc. Natl. Acad. Sci. USA 2011, 108, 15639-15646. [CrossRef]

60. Ngubelanga, A.; Duffett, R. Modeling Mobile Commerce Applications' Antecedents of Customer Satisfaction among Millennials: An Extended TAM Perspective. Sustainability 2021, 13, 5973. [CrossRef]

61. Du, S.; Li, H. The Knowledge Mapping of Mobile Commerce Research: A Visual Analysis Based on I-Model. Sustainability 2019, 11, 1580. [CrossRef]

62. Zhang, S.; Wu, Q.; Xu, S.; Li, G.Y. Fundamental Green Tradeoffs: Progresses, Challenges, and Impacts on 5G Networks. IEEE Commun. Surv. Tutor. 2017, 19, 33-56. [CrossRef]

63. Wu, Q.; Li, G.Y.; Chen, W.; Ng, D.W.K.; Schober, R. An Overview of Sustainable Green 5G Networks. IEEE Wirel. Commun. 2017, 24, 72-80. [CrossRef]

64. Alsharif, M.H.; Nordin, R.; Abdullah, N.F.; Kelechi, A.H. How to make key 5G wireless technologies environmental friendly: A review. Trans. Emerg. Telecommun. Technol. 2018, 29, 3254. [CrossRef]

65. Alaimo, L.S.; Fiore, M.; Galati, A. How the Covid-19 Pandemic Is Changing Online Food Shopping Human Behaviour in Italy. Sustainability 2020, 12, 9594. [CrossRef]

66. Thongpapanl, N.; Ashraf, A.R.; Lapa, L. The Potential Benefits of Offering Suitable Mobile Commerce Experience to Your Customers: An Abstract. In Back to the Future: Using Marketing Basics to Provide Customer Value. AMSAC. Developments in Marketing Science: Proceedings of the Academy of Marketing Science; Krey, N., Rossi, P., Eds.; Springer: Cham, Switzerland, 2017. [CrossRef]

67. Ali Taha, V.; Pencarelli, T.; Škerháková, V.; Fedorko, R.; Košíková, M. The Use of Social Media and Its Impact on Shopping Behavior of Slovak and Italian Consumers during COVID-19 Pandemic. Sustainability 2021, 13, 1710. [CrossRef] 